\title{
Michael Barry (MB) Hooker in Conversation with Kevin Tan
}

\author{
Kevin YL TAN* \\ National University of Singapore, Singapore \\ lawtylk@nus.edu.sg \\ Michael W DOWDLE ${ }^{\dagger}$ \\ National University of Singapore, Singapore \\ lawmwd@nus.edu.sg
}

\section{INTRODUCTION}

In September 201 2, the Faculty of Law at the National University of Singapore (NUS) organized a Symposium on Legal Pluralism in honour of Professor Michael Barry (MB) Hooker, who first coined the term 'legal pluralism' back in I975. Hooker had taught at the Law Faculty between I965 and I968 and from I969 to I970. He returned as Visiting Professor between 1984 and I986. The revised proceedings of this Symposium have been published as Pluralism, Transnationalism and Culture in Asian Law: A Book in Honour of MB Hooker. ${ }^{\mathrm{I}}$ At the conclusion of the Symposium, Hooker consented to a 'no holds barred' interview which took place on 29 September 2012 at the Orchard Hotel. The questions posed to Hooker followed a chronological trajectory, interspersed with thematic interventions. Some of the content of this interview may already be familiar to readers of the abovementioned collection of essays as Veronica Taylor - with the collaboration of Barry and Virginia Hooker - cover much of the same ground, albeit in a different form. ${ }^{2}$

We began by asking Hooker to talk a bit about his personal life. In the second part of our conversation, we discussed his time in Singapore, how he got into the study of adat and Islamic law, the connections that he made, and the people who influenced his work. The third part of our conversation covers the post-Singapore period when he left for the newly-established University of Kent at Canterbury - his most academically productive period. We then discussed his post-academic life in Australia, concluding with some reflections on his life, work, and the state of academic work on Asian law.

\footnotetext{
* $\quad$ Adjunct Professor, Faculty of Law, National University of Singapore.

$\dagger \quad$ Associate Professor, Faculty of Law, National University of Singapore.

The views expressed in this interview are strictly those of Professor Hooker and do not reflect those of the interviewer nor of the Journal.

I. Gary F Bell (ed), Pluralism, Transnationalism and Culture in Asian Law: A Book in Honour of MB Hooker (ISEAS-Yusof Ishak Institute 20I7).

2. See Veronica L Taylor, MB Hooker and Virginia Hooker, 'MB Hooker and Southeast Asian Law: Path-breaking Passions' in Gary F Bell (n I) I.
} 
Abbreviations used:

KT: Kevin Tan

BH: Barry Hooker

\section{NEW ZEALAND}

KT: So maybe we can start at the beginning. New Zealand you were born in ...

BH: Yah, born in New Zealand ... I $7^{\text {th }}$ November 1939 in Dunedin. The war had just started, so my parents had been separated because of the war. My father was assigned to certain duties and my mother was a nurse. So I was brought up mainly by grandparents on a farm ... up in Rakaia, it's a small town in South Canterbury... That's where my mother had a farming family there. Stock farming - sheep, cattle, seeds, special seed planting, you know general farming ...

KT: How big was your family?

$\mathrm{BH}$ : Only my sister and myself, that's all; but thousands of cousins on both sides. Huge extended family [from] both sides ... [My sister] was younger. She died two years ago now. Poor girl, she had cancer ... [My father] was an engineer, specialist heavy engineer. He used to design and make heavy machinery. For the war effort, he was mainly building warships ... He was in Lyttelton Port and in Oakland, Wellington, all over the place, yah. Landing craft, all that sort of stuff ... [My mother] was a nurse ... [She] came from the farm. My father's family were not farmers. No, they were engineers mainly, and miners. They were in mining engineering.

$$
* * *
$$

KT: Do you know about the ancestry of your family? Where your family originates from? ...

BH: Mostly Irish, some Scots and some English. So the usual New Zealand mixture; it's a very typical mixture in New Zealand. First lot came [to New Zealand] from Tasmania [in the I 840s] ... probably they were either convicts or ex-convicts.

KT: And you know this because?

BH: Yah, well, because of family names. Our family names in New Zealand are the same as family names in Northern Tasmania and they were convict families. My sister was always upset by this; I couldn't care less you know.

$$
* * *
$$

BH: So I was just a farm boy, country boy; went to the local convent ... in Rakaia. Then when I became uncontrollable, like I said 'uncontrollable', I was sent away to a boys' school in Christchurch [in late I949] ... about 40 miles away from where we lived. 
I stayed with relatives ... and also with my parents. My parents were together, then apart, [and] then together during the war you know, for that reason. And so sometimes at home, sometimes with relatives and so on.

KT: What was the name of this boys' school in Christchurch?

BH: That was Xavier College ${ }^{3} \ldots$.. [a] Catholic school ... [I] stayed there until school certificate when I was I 5. Then university entrance which I failed. I failed my first university entrance by two marks ... I just didn't do any work (laughs), couldn't be bothered ... In those days, it didn't matter. There were plenty of jobs and anyway we had the farms, I could go back to farming if I wanted to and my father was actually a very influential man in his profession ... he could place me with friends. If I wanted any sort of job at all, he would just pick up the telephone and that was it. There was no pressure on me to do anything ...

KT: So what happened after you failed? Did you do one more year?

$\mathrm{BH}:$ No, ... military service ... I was in the last year of compulsory service - I957 - so I did that in the Air Force ... The army would take anybody, but the navy and the air force could choose ... [B] ecause I had almost got the university entrance they said, 'Yeah, okay, we take you.' ... I was trained as a navigator. [I]t was supposed to be for one year but because it was the last year, they cut the time and said 'Six months only'. So I was trained as a navigator for six months. Then they said, 'You want to stay on and become permanent? Or if you don't want to stay on, you can go.' ... I said, 'I am going.'

$$
* * *
$$

KT: [T]hen what did you do?

BH: Oh, drive trucks, worked in a factory ... I didn't care. I was going to save up money and go overseas. So I was a truck driver, I was a shearer - I was a sheep shearer; worked as a shearer. [After] [a]bout a year then I got sick of it. So I sat down and got out my old school textbooks. And I sat for three months, ten hours a day for three months and went over everything, learned everything. And then sat the university entrance again [in December 1958] and passed it...went to university in '59 ... University of Canterbury, which is in Christchurch ... a small provincial university. There were only 2000 students I think, that's all.

KT: And the choice of law?

BH: I didn't want to be a schoolteacher. Actually my father said, 'Look, you are sure you want to do this because you can go back to farming if you want to or I can find you a good position in engineering firms if you want to? You don't have to do this.'

3. Xavier College was established in 1946 and was operated by the Marist Brothers who had schools on the same site since I888. In I987, it merged with the all-girls Sacred Heart College to form the Catholic Cathedral College. 
KT: Right. So why did you want to do it?

BH: Women, girls, beer, drinking, have fun; just have a good time basically. I did [a] joint law [degree] - BA and Law. BA subjects were mainly History and Philosophy. So I did two degrees simultaneously but I never finished the BA because on the night before the final examination I went to a party and I just didn't turn up at the examination next morning. Like it didn't matter you know. You see in those days it didn't matter. Now you've got to get top grades and pass... I never got one grade ... higher than a B. B was the highest I ever got; everything else was a C, which was a pass. That's all.

KT: Tell me a little bit about what the University of Canterbury was like back then.

$\mathrm{BH}$ : Old fashioned provincial; law was a thing you did for a living. You went to the office and you did conveyancing and you did criminal law and you did family law and that was it. So it prepared you for a very straightforward provincial legal ... high street legal practice, that's it. [T] otally vocational ...

KT: How big was the Law School?

$\mathrm{BH}$ : Well, there were about forty new entrants per year ... that's all. This is provincial I959, I mean things hadn't changed since I939 ... the campus was tiny.

$$
* * *
$$

KT: Okay, so you finished Law School. That would have been in I962?

BH: ' 64 ... I had half a year off. What was I doing? What did I do? I went up north for something with some Maori friends. I don't know what we were doing; I have forgotten now what we were doing. Nothing much, I think. Anyhow, I finished in '64.

Then I did an LLM on top of that, so one more year ... I [had gotten] very interested in Maori Land Law because I had a lot to do with Maoris. Because our family was very closely connected with Maoris, a lot of relatives are married to Maori; we were part Maori, along like that ... So I did an LLM thesis on that. ${ }^{4}$ [When] I got interested in Maori Land Law, there was nobody to supervise me so I didn't have a supervisor. They said, 'You sure you want to do this? Why don't you go and get a job?'

I submitted [my LLM thesis] on time. I don't know who marked it, no idea but it did pay off for me. Because when I applied for my job here in Singapore, I sent a microfilm of that thesis and that's what got me my job in Singapore. Jimmy Montrose ${ }^{5}$ read it and he

4. MB Hooker, An Enquiry into the Function of the Magico-Religious as a Jural Mechanism in Primitive Maori Society, (LLM thesis, University of Canterbury I965).

5. James Louis Montrose (I904-I966) was for 27 years Dean of the Faculty of Law at Queen's University, Belfast. From May I965 to February 1966, he served as Ford Foundation Visiting Professor and Dean of the Faculty of Law at the University of Singapore. At the end of his stint, Montrose, who was seriously ill with cancer, left for Auckland, New Zealand where he passed away on 13 October 1966. See Andrew Phang, 'Exploring and Expanding Horizons: The Influence and Scholarship of Professor JL Montrose' (I997) I 8 Singapore Law Review I 5. 
liked it and he said, 'We'll have this young man.' In the meantime, the Professor of Law in Canterbury, Hamish Gray ${ }^{6}$ who is a very nice man. He said, 'Look, there is a friend of mine in Tasmania. He's a Professor of Law, he's looking for somebody. You can have the job if you want it.'... I said, 'Look, I have just applied for this job in Singapore.' He said, 'What? Where? You are mad!' Well I said, 'Singapore must be more interesting than Tasmania.' ... He said, 'Oh, well, yah I suppose it's different. Yeah, well, alright go to Singapore if you like. If you don't like it, ring me, phone me and come back.'

KT: But why? What made you decide by the end of your LLM that you wanted to be a law teacher or to be an academic?

BH: I had tried and worked in a law office, done quite well. I mean I am very pleased with, 'Yeah, yeah you can stay. We give you this. Do that,' but that was boring. I was very bored. Christchurch was very boring, nothing happens in Christchurch until the earthquake. ... So I was bored, I just wanted to get out. In my generation, everybody left [New Zealand] ... Everybody I knew at university, practically everybody went overseas ... left completely ... They left Auckland, Wellington, the whole lot. Went to Australia, to England, to America, Canada, Singapore a lot, Malaysia.

\section{SINGAPORE}

KT: So how did you know about the job in Singapore?

BH: It appeared in the Christchurch Press. ${ }^{7}$ For God's sake, what the hell was Singapore thinking of advertising in the Christchurch Press is beyond me. I never understood that to this day. The Christchurch Press is an obscure newspaper in a very obscure small town at the other end of the bloody world you know. Why did they advertise? Anyway there it was, so I applied for it just for fun. I mean, you know I thought well, Singapore would be more interesting. ... Next thing I got a telegraph from Peter Ellinger ${ }^{8}$ saying, 'Accept the job.' ... I got to Singapore in January I966, the same day as Geoff (Geoffrey) Bartholomew. ${ }^{9}$ Geoff was in first class, I was down in [economy] class. We didn't know each other.

... You know the funny thing was that the Law Faculty then, there weren't many in the Law Faculty. I can't remember all. There was Tommy [Koh], ${ }^{\text {Io }}$

6. Hamish Gray was appointed the first Professor of Law at the University of Canterbury in I957.

7. The Press of Christchurch was a daily broadsheet published in Christchurch since I86I.

8. E Peter Ellinger (b I933) joined the Faculty of Law, University of Singapore in I96I and taught there till I 967 when he left to take up a chair at Victoria University, Wellington, New Zealand. In I977, he moved to Monash University, Melbourne, Australia and remained their till 1986 when he returned to NUS where he became its first Emeritus Professor of Law.

9. Geoffrey Wilson Bartholomew.

Io. Tommy TB Koh (b 1937) was among the first batch of students of the Faculty of Law, University of Malaya. In I96I, he graduated with First Class Honours and then joined the Faculty as teaching staff, becoming its first locally-trained scholar to become a full professor in 1977. Koh gained wide recognition for his work as a diplomat and negotiator and has, since 1974, been on secondment from the University to 
Jaya ${ }^{\mathrm{II}}$ hadn't quite come, Su Mien, ${ }^{\mathrm{I2}}$ Sook Yee, ${ }^{\mathrm{I3}} \mathrm{Molly}^{\mathrm{I4}} \ldots$ [T] hey had all turned up at the airport to meet Geoff Bartholomew. But Geoff had been very crafty and had slipped out the back entrance or something. So there was no Geoff, they were left with me. I thought, 'How nice of them to come and meet me,' but actually they hadn't come to meet me at all.

KT: This is the faculty in ' $66 \ldots$

BH: ... Joseph Minattur, now he was a funny one ... He's mad. I mean he was certified to be mad. He used to live in College Green. We had a house in College Green. Joseph was there and screams came out one evening from his house. So we all looked out what was the matter with Joseph and he had the maid backed up in the corner in the kitchen and he was drunk, saying, 'Oh, look my dear, I am a doctor. I am Doctor Minattur. I am going to examine you physically. Now, take off your clothes, take off your clothing.'

... David Buxbaum, ${ }^{\mathrm{I} 5}$ and Francis Trindade $^{\mathrm{I} 6}$ were there; so was George Venturini. ${ }^{17}$ George had paranoia. He thought that the police were watching him. The first thing he said to me was, 'You must be very careful in Singapore. The police, the Special Branch they watch you.' 'But for what? I am not doing anything.'

the Ministry of Foreign Affairs. From I97 I to I974, Koh served as Dean of the Faculty of Law, University of Singapore.

I I. Shanmugam Jayakumar (b I939) graduated top of his class at the Faculty of Law, University of Singapore in I 963 . He joined the Faculty as a member of the teaching staff and from I 974 to I980 served as Dean of the Faculty. Jayakumar entered politics in I 980 and served in numerous key positions including Minister of Law, Minister of Foreign Affairs, Minister for Home Affairs, Coordinating Minister for National Security, Deputy Prime Minister, and Senior Minister.

I 2. Huang Su Mien (better known by her married name, Thio Su Mien) was among the first batch of students of the Faculty of Law, University of Malaya. As one of the top students in her class, she was recruited as a member of the Faculty in I962. In I968, she became the first local law graduate and woman to become Dean of the Law Faculty, a position she held till I97 I when she resigned and left the University for private practice.

I3. Chung Sook Yee (better known by her married name, Tan Sook Yee) was a graduate of Trinity College Dublin. She joined the Faculty of Law, University of Singapore in 1964 where she taught till her retirement in 2005 . From I980 to I987, she served as Dean of the Faculty of Law.

I4. Molly Cheang was the top student in the Law Faculty's graduating class of I962. She joined the Faculty of Law in 1965 and taught there till 1985 when she left to join the University of Malaya.

I 5. David Charles Buxbaum (b I 933) was an American lawyer who had been at New York University and the University of Michigan. He joined the Faculty of Law at the University of Singapore in 1963 and left in 1965. A specialist in Chinese law, Buxbaum claims to have been the first American lawyer to be invited to China to represent American business interests back in 1972 after President Richard Nixon's historic visit. At the time of writing, Buxbaum is Managing Partner of international law firm, Anderson \& Anderson LLP.

16. Francis A Trindade was educated in Karachi and Oxford and began his academic career as an Assistant Lecturer at the Faculty of Law, University of Singapore in 1963. In I966 he took up an appointment as Lecturer in Law at Monash University where he became Sir Owen Dixon Professor of Law in 1987. He retired as Emeritus Professor in 2002. See 'Tribute to Professor Francis Trindade' (2009) 35(2) Monash University Law Review I9I.

I7. Venturino Giorgio Venturini (b I928), better known as Dr George Venturini. A former advocate at the Court of Appeal in Bologna, Italy, he retired from Monash University in I993. 
'That doesn't matter. They put you in prison.' He had a sort of persecution complex ... [He] left shortly after we came. George carrying his paranoia and he gave a speech at his farewell dinner saying the police are here and we are all being watched ...

[He taught] Company Law and the funny thing was George was Italian; he had learned English Law and written his thesis on Company Law. His thesis was a bloody great big huge thing like this. That was the set textbooks for the Company Law students in Singapore. ${ }^{\text {I8 }}$ George's thesis was a set textbook. ... I mean this would never happen today of course, never be allowed to happen. But nobody had any control at that time over anything. I mean people would do the maddest things. Joseph Minattur would give lectures about how the name Malaya really comes from Malayalam in India and the glories of Indian civilization. And the Chinese students who sit here, they go, 'God, what is this?'

So anyway, bloody old Venturini and his Company Law thesis textbook, I think Geoff Bartholomew put a stop to it ... But nobody else took any notice you know.

$$
* * *
$$

KT: Was Dai Davis here at that time?

BH: No, but he came through later. He was on a visit after being sacked from yet another university. You know his career was one of the - there's a thing they used to call unkindly 'the WOG's circuit'. Very unkind, you heard about this?

\section{KT: 'Western Orientalized Gentleman'?}

BH: Yeah, yeah, yeah. It happened in I940s, I950s. Singapore was on the tail end of this. You were no good; you couldn't get a job in England, so you went to Cairo, then from Cairo you went to Khartoum. [From] Khartoum you went to somewhere in Africa - West Africa, normally Uganda or somewhere like that. Then maybe you ended up in Bangkok. Singapore was a stage imposed, Singapore and Hong Kong. When they got sick of you, you then went to Canada. So you went Saskatchewan or Alberta in Canada or sometimes you went to Australia; you went to Perth or Queensland. This is the WOG's Circuit; the hopeless cases. So Dai Davis was one of the hopeless cases. Geoff Bartholomew was in a way [on it as well] ... He was very proud of it. 'See, I have been on the WOG's circuit,' he'd say. I have done that one. 'You haven't done Khartoum?' I said, 'No, I have not.' He said, 'You missed a lot.'

$$
* * *
$$

KT: So when you came, where did you go? I mean you landed at the airport and all these members of the faculty were there ...

BH: Tommy [Koh] took us to the Orchard Hotel ... the old one, which was just a little concrete box. I mean the toilets didn't work, the lifts didn't work, the stairs didn't

I8. VG Venturini, Cases and Materials on Company Law in Malaysia (1964-I965) in six parts. 
work. It was dirty, it was just a dump you know but it didn't matter ... Then to Dalvey Road Mess, ${ }^{19}$ you know the big Dalvey Road Mess, the big old house ... That was such a lovely building, it was so beautiful. I loved being there.

KT: Oh, you were there only for a few weeks and then to ...

BH: College Green ... That was good. George Venturini was just a neighbour. There was Ruth Darusman ... She was in Epidemiology and so on but she was a neighbour.

$$
* * *
$$

KT: Alright, and so when you reported for work, of course Geoff was then the new dean right?

BH: Geoff was the new dean. He said, 'Okay, what do you want to do?' I said, 'I don't know.' He said, 'Okay, will you do Introduction to Law because I am short of staff.' And the reason why all of the local staff couldn't do it? I realized later of course that the local staff had no bloody intention of doing Introduction to Law but he was going to ask me. But as it turned out, that was really a bit of luck, good luck for me because you see, it would require me to teach Islamic law, a bit of Malay customary law ... [T] hey had manuscripts, so I had to learn to read the manuscripts. I got sort of interested in those. Then I had to learn Islamic Law because Malays are Muslims ...

I [first] learned it myself and then I went to live in a kampong in Negeri Sembilan ... [a]nd learned Minangkabau Malay ... [E]verybody said you must go to Negeri to do Adat Perpatih ... which is supposed to be immemorially ancient and so on. But it is [not]. [For example], the constitution of Negeri Sembilan ... it was made up in I9I9 by a man called Nathan ${ }^{20}$ who was a District Officer in Kuala Pilah. [H]e took bits and pieces and wrote them down and ... then Winstedt said, 'Yeah, okay, that's your constitution.' ${ }^{21}$ Winstedt $^{22}$ was quite a powerful man ... And then [in I908] Taylor $^{23}$

I9. This building has since been demolished.

20. Julius Ernest Nathan was a Yorkshireman who came to Malaya in I904 as a member of the Malayan Civil Service (MCS). He served as a District Officer in most states of the Federated Malay States and then as Controller of Rubber. He retired from the MCS in I 924 and joined the firm of Francis Peek \& Co in London. Starting from 1944, he assisted the British Broadcasting Corporation's Malay service by broadcasting in Malay. See 'Spotlight on Malaya and Malayans' The Straits Times (Singapore, 22 September 1946) 2.

2I. JE Nathan and RO Winstedt, Johol, Inas, Ulu Muar, Jempul, Gunong Pasir and Terachi: Their History and Constitution (Baptist Mission Press I920); see also Richard Winstedt and PE de Josselin de Jong, 'A Digest of Customary Law from Sungai Ujong' (I954) 27(3) Journal of the Malayan Branch of the Royal Asiatic Society I, 5 .

22. Richard Olaf Winstedt (I878-I966), more popularly known as RO Winstedt, was a high-ranking colonial administrator, historian and orientalist. He joined the Federated Malay States Civil Service in I902 and was posted to Perak where he studied the Malay language and culture. Winstedt served as District Officer in Kuala Pilah between I9I3 and I9I6, before being posted to the Education Department. From I928 to I93 I, he was the first President of the Raffles College in Singapore. When he retired from the MCS in I935, he returned to London where he became Lecturer, Reader and then Honorary Fellow at the School of Oriental and African Studies at the University of London.

23. EN Taylor joined the Malayan Civil Service in I92 I, serving in various administrative appointments in the Malay States until I936. In I938, Taylor was called to the Bar by the Inner Temple and transferred to the Colonial Legal Service. He served variously as Official Assignee and Public Trustee and after the War, 
and Mackray, ${ }^{24}$ who were two District Officers in Rembau, sat down and wrote up the matrimonial inheritance tribal system ${ }^{25}$... They made a big chart of this, gave it to the Malaysians and said, 'This is your history. ${ }^{26}$ So it is not immemorially old. It's a pure colonial official invention. But don't say that now - [Malaysians will] get terribly upset: 'Did he say that? Oh, no, don't you dare!'

KT: So how did you make connections with the Negeri people?

BH: That was Suffian - Tun Suffian ${ }^{27}$ did this ... I just got here in January. For some reason there had been some stuff up about examinations here and he had to come back for some special external, whatever it is. So he got a dinner of course and I was invited, so I went. And he said, 'Yah, who are you and what are you doing?'

I said, 'I ... teach Introduction to Law in Malaya, but I don't know anything about this.' 'No problem,' he said, 'the State Secretary of Negeri Sembilan is an old friend of mine. I'll write to him, tell him to help you.' And sure enough two weeks later I got a letter from the State Secretary in Negeri Sembilan saying, 'Tun Suffian tells me you want to come and learn adat here. Please come and see me in my office at such and such time.'

So I went up to Seremban, and there he was. 'I can't do this personally, I am too busy,' and so on. He was a high ranking official. 'I have arranged for the District Officer (DO) at Kuala Pilah, he would help you. So go to Kuala Pilah.' So off I went and turned up at the DO's office. The DO was a nice man. ${ }^{28}$ 'Oh, welcome, welcome. Yes, I know all about you. But I can't help you because I am too busy, but I give you my Chief Clerk, Tunku Ibrahim. ${ }^{29}$ Tunku knows everything which was absolutely true. He was

Custodian of Enemy Property. In 1947, he was elevated to the Bench as Judge of the Supreme Court of the Malayan Union. See 'Custodian is made Supreme Court Judge' The Straits Times (Singapore, I7 April I947) I.

24. William Henderson Mackray (I 877-I920) was an Oxford-educated Malayan Civil Service officer who arrived in Malaya in I90I and spent 'a greater part of his service in Negeri Sembilan' and was later appointed Acting Under Secretary of the Federated Malay States. See 'Late Mr William Mackray' The Straits Times (Singapore, 23 May I922) 9.

25. It appears that Hooker conflated the works of Mackray and Taylor. Mackray had written a book on Rembau with Major CWC Parr (see n 26) while it was Taylor who wrote up the 'law' on distribution of property upon the dissolution of a marriage. See E N Taylor, Malay Family Law: An Essay on the Law and Custom Relating to the Distribution of Property on Dissolution of Marriage Among Peninsula Malays with Illustrative Cases (Printers Ltd 1937); and E N Taylor, 'Inheritance in Negri Sembilan' (I948) 2I(2) Journal of the Malayan Branch of the Royal Asiatic Society 4I.

26. See CWC Parr and WH Mackray, 'Rembau, One of the Nine States: Its History, Constitution, and Customs' (I9I0) 56 Journal of the Straits Branch of the Royal Asiatic Society I.

27. Tun Mohamed Suffian bin Mohamed Hashim (I9I7-2000) won the Queen's Scholarship to study law at Cambridge in 1936. When he returned to Malaysia in I946, he joined the Judicial and Legal Service and became a Magistrate in Malacca in I948. In I96I, Suffian was elevated to the Bench and served as Judge in the High Court of Kuala Lumpur. In 1973, Suffian was appointed Chief Justice of Malaya, and in the following year, became Lord President of the Federal Court (Malaysia's highest judicial office), a position he held till his retirement in I982. He also served as External Examiner at the Faculty of Law, University of Singapore for many years.

28. This was most probably Mohd Tajol Aros bin Ahmad, then District Officer of Kuala Pilah. He was acknowledged in MB Hooker (ed), Readings in Malay Adat Laws (Singapore University Press I970) x.

29. This was Tengku Ibrahim al Haj, then Clerk of the Kuala Pilah District Office. He is acknowledged in Hooker (n 28) x. 
a clerk in the Land Office; he knew the land records back to front. He knew the land regulations. He was himself a Lembaga Adat ${ }^{3 \circ}$ chief; he was an educated Muslim... [He] was a Senior Clerk, he was Chief Clerk of the whole district ... [H]e was much older. My father's age, in fact. Yeah, yeah, much older. So luckily he took a liking to me and I learned everything from him.

KT: So by that time you could speak some Malay already?

BH: No, nothing. He started me off. So we started together. He said, 'You read this like that and you read this like that and you pronounce like this and this is what you do. But this is not Islamic law, this is adat. I was getting free tutorials every day from the leading expert for nothing...

I stayed in the rest house, there's a rest house in Kuala Pilah; lovely old place, stayed there. There was Mr Wong, he was a very nice man. Nothing was too much trouble, [he would] do anything. I'd come back, very tired, cold beer straightaway, didn't even have to ask. Cold beer, 'I thought you might like a sandwich, so here's sandwich and cold beer.' If I wanted anything at 2 o'clock in the morning, he'd come out. 'Yah, I'll do this, I'll do that.' He's such a nice man.

KT: So how long did you have this connection with Negeri Sembilan, on and off?

BH: Well, as long as I was here, all the time. But then I took a break from that. A friend of mine ... Geoffrey Benjamin ... was doing his anthropology fieldwork in Temiar in Kelantan ... I was interested in Semai because of the land tenure problems. Seisin, agriculture, occupation of land, was it squatting or was it true occupation? Were there any native title rights? This was before native title was even thought of. I was taught that there were native title rights but the ordinance would not allow this; the aboriginal peoples' ordinance would not allow this. So I thought, 'Well, I better go and find out more about these Semais'.

So I rang up Suffian again, 'Suff, I want to go.' And he said, 'You are off your head, you are mad! Look, you'll get sick. You'll get malaria, you'll get dengue. You'd get bloody fever.' And true enough, he was dead right actually, I got malaria. Anyway, he rang up to JOA (Jabatan Orang Asli, ie, Department of Aboriginal Affairs), and they said, 'This mad, bloody person wants to go.' 'Yeah, yeah no problem.' So I went up to... Ulu Slim, Kampong Ulu Slim, you know Slim River. Sungai Slim ... I stayed in an aboriginal village - a Semai village. I took a tape recorder and I used to tape their music, they are beautiful singers. So I taped all their songs, they are all in the Universiti Kebangsaan Library, all those tapes. I sold my library to the UKM (Universiti Kebangsaan Malaysia, ie, National University of Malaysia), which included those music tapes. 
KT: So it all started with this land thing with the Maoris?

$\mathrm{BH}$ : Yeah, that's right ... So that was my orang asli experience.

$$
* * *
$$

KT: So the kind of people you tended mix around with socially and intellectually would not necessarily have been the law people.

BH: No, not law people at all ... anthropologists, English literature people, I knew a lot of them. Language people; Yock Fang ${ }^{3 \mathrm{I}}$ and all that lot, people who were doing Malay or Arabic or whatever. And I had a lot of friends and contacts down in Kampong Glam down in Arab Street and Bussorah Street [in Singapore]; booksellers and so on. I used to go down and buy books, you know the kitab kuning. I used to buy kitab kuning ${ }^{32}$ a lot. And they say, 'You are Muslim?' 'No.' 'Well, you are a white person, why are you reading kitab kuning?' I said, 'I am interested.' 'Ah, probably you really will like to become Muslim. So let's discuss the religion.'

So I go and buy a book and I spend all day there actually talking theology. One of the advantages with my Catholic school education was that theology was a compulsory subject in our final two years. So I was easily able to cope with kadis and imams and alim on theology. It's actually not so different; theological method. But I have done philosophy, logic and so on, so I could easily talk to the most educated people. No problem.

KT: And by that time your vocabulary had been ...

BH: Malay was okay and I was starting Arabic at the same time. I just learned it here [in Singapore], studied here, yah. Started here ... [s]till learning, I am still learning.

KT: You sat down, you bought a book, you looked at it or ...

BH: Yah and I mixed with people who were speaking it all the time. My first wife was from Cairo and she was a fluent Arab speaker. She couldn't read it because she'd never been to an Arab school. She went to Europe ... She was Albanian ... brought up in Cairo. She could speak Arabic but not read it because she went to European schools, not to Arab schools. So she could also speak Arabic... The language [in Southeast Asia] is not the same as Cairo Arabic, no. So, yah I mixed with those people down there who were Malays, Arabs. Yah, that's right.

3I. Liaw Yock Fong (I936-20I6) was a renowned philologist, scholar and expert of the Malay language and literature. He was a lecturer at Nanyang University from I966 to I98I and then taught in the Malay Studies Department at NUS till his retirement in I996. Liaw authored more than twenty books including his magnum opus, Sejarah Kesusasteraan Melayu Klasik [History of Classical Malay Literature] (Pustaka Nasional I975). He was also active in researching old legal manuscripts, including Yock Fang Liaw and Hassan Ahmad, Undang-undang Melaka dan Undang-Undang Laut [The Melaka Laws and The Maritime Laws] (Yayasan Karyawan 2003).

32. Literally 'yellow books', referring to the cheap paper upon which the classical texts of Islam in the Arabic script are printed. 
KT: So that brought you on to all this research about adat and old manuscripts and that sort of things. What about the legal history part because you did a lot of work on legal history?

BH: Well, it all fits in together because you have to know. Here are these people who are doing Islam, Muslims here. So, Islam is not native to this region, it came, which means that there are local records and so on. Which means plenty of government policies, plenty of legal policy and then it was not just here. There was the Dutch in Indonesia, so I had to learn that. And then there was the French in Indochina, because colonial legal policy is not the same. But fortunately my French was okay, I had done it at school. Learned a bit of Dutch. Latin was okay for the Spanish and then one of my colleagues for the Portuguese, it's a hell of a language - you can read it with a dictionary if you know Latin but you can't speak it. It's absolutely impossible ... I had a colleague in England - John Willis who's a fluent Portuguese speaker because his grandmother was Portuguese and he was brought up in Lisbon. So he learned to speak it as a baby. He said, 'That's the only way you can learn to speak Portuguese, it's as a baby. Otherwise you can't speak. It's an incredible language.

$$
* * *
$$

KT: Who else were your neighbours at that time? ... At the Law Faculty, office-wise?

BH: There was an Indian visiting professor ... He had finished his PhD at Oxford; he got a grant to come here for some reason, I don't know why. And he was preparing that $\mathrm{PhD}$ for publication. It was published by Clarendon Press in Oxford. He asked me to correct his English, so I did all the English for him, which was a small job because his English was very good actually. There was another Indian professor from Rajasthan. I forgot his name now; he was a nice man.... Oh, we had the Americans and the Canadians... These were people appointed like me, as assistant lecturers or maybe lecturers even for three-year contracts. I don't know what the hell Geoff was doing, appointing these people.

KT: I think it had something to do with the Ford Foundation Grant ... So he had to hire Americans.

BH: And they were hopeless, absolutely bloody hopeless. They were here; we call them the honeymoon couples because they are all just mad. They came here and they made it quite clear they were not interested in Singapore. That they use Singapore as a base to go touring around, have a holiday, not interested in local law. They didn't want to be bothered with anybody else and they were unpleasant and nasty and arrogant people. And the local staff hated them; I know that. The office staff you know, Mr Young Cheng Wah, ${ }^{33}$ he said to me one day, 'Barry, Barry what are we doing with these people? Get rid of them.' 'I can't get rid of them.' Oh, they were horrible, nasty.

33. The late Young Cheng Wah was an Administrative Assistant in the University of Malaya. In I956, he was seconded to the Law Department to provide Professor LA Sheridan with administrative support to 
KT: Who were the inspirational guys? Who were the guys who you thought were really trying their utmost to do something good with the Law School?

BH: I don't know. Actually Geoff ...

KT: Did you get along well with Geoff?

BH: Yeah, very well. Yeah, yeah, yeah ... He was very good. He was a good boss, very good ... but Geoff was having a hard time at the end, I know, when Su Mien had to become Dean ... Su Mien was a terrific boss, I'll tell you that. She was great.

KT: That was when Vice-Chancellor Toh Chin Chye ${ }^{34}$ of the University of Singapore started his anti-expat campaign?

BH: This was Toh Chin Chye. But he picked on me first you see because I was badly dressed. I wore shorts and I didn't look very good... But he attacked Su Mien and said, 'You are only a woman and you can't control these expatriates. Look at that man there.' So he attacked me through her and he attacked her. She was very, very upset. And I thought what a shitty thing, what a low thing to do. If you wanted to attack me, okay attack me, right, but not through a woman. That was pretty low I thought.

Toh Chin Chye was a funny man and I did meet him socially some time later when I was sort of cleaned up a bit. And he must have been in a good mood or whatever, he was nice, helpful, charming. 'Anything I can do? What are you doing? Oh, that's very good.' My scientist friends told me, he was a very good scientist. He wasn't going to get the Nobel Prize but he was very respectable and confident scientist ... [B] ut he had this thing; very touchy, very sensitive and if he thought that you weren't paying him proper respect or whatever, he'd go mad ... He was actually quite a nice person if he just relaxed a bit.

BH: But you asked about the inspiring people, the problem was the Law Faculty was very small. There was Tommy and Jaya but they were taken off; the government wanted them. ${ }^{35}$ So, Su Mien who had her hands full running this place and

establish the Law Department. For the first decade of the Law Faculty's existence, Young ran its administration single-handedly. Later, when more administrative staff joined the Faculty, Young presided over its efficient running until the early I990s when he took a back seat and handed the reins of administration to Lim Swee Tee. For twenty-five years, Young also served as the Secretary for the Board of Legal Education. He died, aged 60 on I 2 February 1995. See Andrew Phang Boon Leong, 'Mr Young Cheng Wah - A Personal Appreciation' (1995) I6 Singapore Law Review 23.

34. Toh Chin Chye (I92 I-20I2) was an academic physiologist and founder-chairman of the People's Action Party (PAP). In 1959, when the PAP formed the government, Toh served as Deputy Prime Minister (I959-I968) while concurrently holding on to his position as Reader in Physiology at the University of Malaya (and later University of Singapore). In I968, he was appointed Vice-Chancellor of the University of Singapore, and concurrently, Minister for Science and Technology. He held both posts till I 975 when he became Minister for Health. Toh retired from the cabinet in I98I, but remained Member of Parliament for Rochor until his retirement from politics in 1988.

35. Hooker was referring to the time when Tommy Koh and S Jayakumar were seconded from the University to the Ministry of Foreign Affairs to serve as Singapore's Permanent Representative to the United 
Sook Yee, Kheng Lian ${ }^{36}$ were working very quietly. They didn't make a big splash or anything ... Leonard Pegg ${ }^{37}$ came later and yeah, he tried to get the students gingered up a bit you know but they weren't going to. They just wanted to get enough information to pass the examination properly, the usual.

KT: Any outstanding students you remember from your time?

BH: Yeah, there were three actually. There was Eunice Chee, ${ }^{38}$ I think Eunice was in practice here in Singapore ... Don't know what happened to Eunice. Anyway, I think she had a practice. And Helen Chandran, ${ }^{39}$ who was a Malaysian Indian. Helen was very good. And Ainum ... Ainum Mohd Saaid. ${ }^{\circ}$ She became Solicitor-General, I think, of Malaysia and Head of the Malaysian Stock Exchange... Ainum was very good. I taught her brother; her brother came to me in Canterbury in England with a PhD. That's Shaharuddin Mohd Saaid. He was Dean of UKM Law School ... So I taught two members of that family; both very clever.

KT: What about other scholars around the university?

BH: Well, it's strange you should ask that because the Law Faculty did not have a strong traditional scholarship, did not at that time... The strengths [at NUS] here were in ... I understand in science, but I can't really say because I am not a scientist. But I know that apparently there were some very good scientists ... in the medical school, yeah.

The English Department was incredible because you had Dennis Enright who was a poet, Paul Theroux a novelist, David Atkinson who became a leading critic ... and Norman Sherry who was a biographer of Conrad ... [T] hose four made this one of the strongest English Departments in the Commonwealth. Incredible!

Nations. Koh served from I968 to I97I, and then again from I974 to I980, while Jayakumar served from I97I to I974. Jayakumar was to leave the University again in I980 to enter politics, but this was beyond the time frame Hooker was referring to.

36. Lim Kheng Lian (b I937), better known as 'Koh Kheng Lian' is a pioneering local legal academic. She was among the first batch of graduates of the University of Malaya's Faculty of Law. After graduation in I96I, she taught law briefly at the Singapore Polytechnic (I96I-I963) and then joined the teaching staff of the University of Singapore's Law Faculty where she has remained since. In I996, she became the founding Director of the Asia-Pacific Centre for Environmental Law, a post she held till 2017. In I997, she was made the Law Faculty's second Emeritus Professor. She was inducted into the Singapore Women's Hall of Fame in 2014.

37. Leonard Pegg (b I943) is a legal academic specializing in family law. He joined the University of Singapore's Faculty of Law in the 1967 session, and among other things, served as Sub-Dean of the Faculty. He resigned from the Faculty in I97 I to join the University of Hong Kong.

38. Eunice Chee Ai Lien, Class of I97I. Chee practised as a conveyancing lawyer and was partner at the firm of Shook Lin \& Bok and later a Director of TanJinHwee LLC.

39. Helen Chandran, Class of 1970 . She later migrated to Australia.

40. Ainum bte Mohd Saaid (b I946), Class of 1970 obtained an LLM (magna cum laude) from Vrije Universiteit Brussel. She has held several high-profile offices, including being the Deputy Chief Executive of the Securities Commission of Malaysia (I999-200I); and in 200I, she became the first woman Attorney-General of Malaysia. Her tenure was short-lived and she resigned at the end of 200 I to join Laura Ashley Holdings PLC as Chief Legal Advisor in 2002. 
And they did not suit Dr Toh, because they were disreputable. They drank too much and made jokes about Singapore ... Toh Chin Chye could not stand them. And neither could the Foreign Minister then [S Rajaratnam]. He said, 'This man Enright, he is a mendicant professor.'

KT: That's right. He called him the mendicant professor. And Enright wrote a book called the Mendicant Professor.

BH: That's right. He got the last laugh. That's why they all left in the end, they all went but they took with them some very good Singaporean literature people. Shirley Choo. You probably never heard of Shirley Choo. [Dennis Enright] said to Shirley, I was there, 'You can't stay here. This place is an intellectual desert, it's full of monkeys. It's full of idiots. That's you Singaporeans.' This is the language he spoke. And she said, 'What shall I do? I have got to have a job.' 'No problem,' he said. Two days later he came back, she told me, 'Dennis Enright has fixed me up with a job at the University of Sheffield, full lectureship tenured. No interview, nothing, I just pack my bags and go.'... But she was very good and that's a real loss to Singapore, you see. A real loss ...

And there was - I've forgotten her name - Chinese taxonomist. She worked partly for the Department for Science here - Faculty of Science and partly for the Botanical Gardens Science. She was the only taxonomist, not just in Singapore but in Southeast Asia. The only trained taxonomist. And some bloody little clerk in some department somewhere refused her ... not-unreasonable demand. I don't know what it was for; a new room or a few dollars for some equipment or something. Told her no and so she packed up and left... She went to Australia, straight into a readership ... [S] he was only a lecturer here, straight to a readership.

BH: [T] he university in those days was held back here very much by incompetent management style. Very, very poor quality. So you had some real problems with them you know. They were basically Grade C clerks who had been promoted above their abilities, were terrified to do anything or make a decision, so they did nothing. Or if they did something, if they made a decision, it was always 'No' to be safe. So, they were applying for safety, their safety. They wouldn't do anything.

I ran across them in the Registry because I had Ford Foundation money to go and do this fieldwork with the orang asli at Sungai Slim. And I put in that I had to buy a battery, I bought a tape recorder and then I had to spend money of course. So when I came back, I gave the battery to Selamat who gave it to whoever. So that was fine. Tape recorder I gave to Groves who was Professor of Sociology to use in his department. Yah, that's fine, no problem. Then I put in my accounts of how I spent the money and so on, I got this bloody little clerk, he came and said, 'Where are the receipts?' I said, 'Look, these people are illiterate. They are in the jungle, they cannot read or write.' 'But I need this.' But there were four more complaints. Poor old Geoff had to take all this crap you know. Because I went to him and said, 'Receipts.' So he had to fight the accountants, idiots. 
KT: Didn't you also end up editing or deputy editor of the Malaya Law Review for a while?

BH: I did. Ah, this is a joke. When I first came here ... [w]ell, the youngest member of the staff always gets all the tough jobs ... 'Right, you would be Finance Manager of the Malaya Law Review.' That was I966. I said, 'Look, I am not all that good with money, you know,' because when I got married my mother told my wife 'you look after all the money; he is hopeless.' So I said, 'That's true.' And then I went into the Malaya Law Review room, they had a little office next to mine. There was a whole pile of unopened envelopes on a desk full of cheques. MLJ Rajanayagam was supposed to be the Finance Manager. He didn't even bother opening the envelopes, so some cheques were okay, most were out of date ... And the accounts ... there was no mailing list, the accounts were in a total shamble, total mess. I couldn't handle this, so I got hold of a nice man called PS Senna. He was in the Accounting Department and I said, 'Come on, look, we got to start from scratch. This is what's in the bank, this is what I think we have got.' So we started from scratch but he set up an accounting system for us.

KT: So you were Finance Manager but then eventually became the Editor?

BH: Editor for one year ... [b]ecause nobody else would do it.

KT: Was that the year you did that special edition with Kyshe? ${ }^{4 \mathrm{I}}$

BH: Yah, you should have heard the profession scream here! They went up through the bloody roof, 'What's this rubbish? What's all this history rubbish? No importance!' 'We want law reports, we want cases, we want comment on cases.' Yah they went bloody ... the legal profession went mad ... [T] hat copy, if you've got a spare copy anywhere, John Randall's bookshop, Oriental Bookshop in London was selling at $£_{50}$ each ... [t] hat was in London, twenty years ago!

There was a source book too which was actually very useful. ${ }^{42} \mathrm{I}$ know the former Law Librarian in University Malaya; she had a stack of these. She had about ten of them and every visiting person who came through asking about Malaysia law, she used to give them a copy. She said that the word got around and she would get written requests for them you know. It was a great success that little book ... I mean it's totally out of date now and the approaches are wrong now but for its day, it was a very good book - very pleased with that.

$* * *$

4I. James William Norton Kyshe (I8 55 -I920) was a British colonial administrator who served as Registrar of the Supreme Court of Hong Kong from I 895 to I 904 . Prior to his appointment in Hong Kong, Kyshe served as Assistant Registrar of the Supreme Court of the Straits Settlements during which time he compiled and published his Cases Heard and Determined in Her Majesty's Supreme Court of the Straits Settlements (Singapore \& Straits Printing Office I 885-1890) in 4 volumes. In volume I of this valuable collection of cases, Kyshe provides a 'Judicial History of the Straits Settlements I786-I890' which Hooker excerpted and published with an introductory essay as a special issue of the Malaya Law Review - 'A Judicial History of the Straits Settlements I 786-I 890' (I969) I I (I) Malaya Law Review 38 . It is this I969 reprint that Hooker refers to in the interview.

42. MB Hooker (ed), A Sourcebook of Adat, Chinese Law and the History of Common Law in the Malayan Peninsula, Malaya Law Review Monograph No I (Faculty of Law University of Singapore I967). 
KT: Right. Before we get to Kent, last bits of Singapore. Bashir Mallal ...

BH: Yeah, he was such a nice man. He was so generous. [I met him] at the same dinner I met Tun Suffian; at the examiners' dinner. 'Oh, yes, yes the Malayan Law Journal, come and see me anytime. Any books and so on I'll get the books for you,' and all that. So I went to Malacca Street ... Mansor ${ }^{43}$ was there and they had some books for sale. So I needed some textbooks, so I got some books and I said to Bashir, 'Look Mr Mallal, I haven't got the money with me now but end of the month, okay?'

And he said, 'Yeah, that's okay. That's okay. Pay me end of the month.' I took the books, went down the stairs, Mansor came behind me - Mansor said, 'Hey, look Barry, Barry look, actually we need the money. Can you get some money next week?' He said if I leave it too long Bashir would say, 'Just give the books.' Bashir would just give it to me, he's very generous. So I got the message you know ... I also always paid earlier because he was so generous. He would just give them away.

$[\mathrm{H}] \mathrm{e}$ helped a lot, when he found out that I was interested in Islam, Islamic Law and so on, introduced me to kadis, to imams and so on. 'These are my friends and they will help you.' He opened huge numbers of doors for me here. So, [as] with Suffian in Negeri Sembilan, the doors opened everywhere. So I was so lucky. As I was saying yesterday, I just wish that people who come after me had anything like the luck I had here. I was so lucky with people.

BH: Eusoffe Abdoolcader ${ }^{44}$ was a lovely man ... He was on the [Malaysian] Federal Court with Suffian ... He was a very shy man, terribly shy. And you had to see him a lot before he would start to open up a bit. After a while, he is very slow and then after a while he would open. But he was like Bashir Mallal, he was one of the few people you could say he was a truly good - no fault. No flaws, no faults, nothing - just a perfectly good person: very rare, you know, very rare.

BH: Lee Hun Hoe ${ }^{45}$ I knew very well in Borneo because I worked over there for a while ... [He wrote] two books on native laws in Sabah and Sarawak ${ }^{46}$ - I wrote the introductions too. He arranged me to go there [in the I970s]. There was a thing called

43. Al-Mansor Adabi (I928-I988) started life as a school teacher and was later hired as Assistant Editor and then Deputy Editor of the Malayan Law Journal by Dr Bashir A Mallal. Mansor had gained prominence by having his marriage to Maria Hertogh in 1950 annulled.

44. Eusoffe Abdoolcader (I924-I996) was one of Malaysia's most prominent and erudite judges. The son of prominent lawyer and politician Sir Husein Hasanally Abdoolcader (I890-I974) Eusoffe Abdoolcader graduated with First Class Honours from University College, London and was called to the Bar at Gray's Inn in I950. After practising for 24 years, he was elevated to the High Court of Malaya in I 974 and was promoted to the Federal Court in I982. For many years he served as External Examiner at the Faculty of Law, NUS. Depressed by the death of his wife, he committed suicide in 1996.

45. Lee Hun Hoe (I92I-2005) was Chief Justice of Borneo from I974 to I990. He was born in Kedah and obtained his law degree from the University of Southampton after which he joined the civil service and later transferred to the Judicial Department. In 1965, he was appointed Judge of the High Court of Borneo and became Chief Justice in 1974 and held the post till his retirement in I990.

46. Lee had certainly written one book on native law - Lee Hun Hoe, Cases on Native Customary Law in Sarawak (Kuching: National Printing Department 1976) but his 'Customary Laws in Borneo (Sabah and Sarawak)' (I989) was a conference paper delivered at the International Conference on Malay Civilization II held from I 5-20 August 1989 in Kuala Lumpur. Hooker may have conflated both publications. 
the Sabah Foundation and the Sarawak Foundation. These were basically political slush funds used for payments here. Anyway, somehow, he managed to [convince] the State Secretary that it would be a good idea to have me there to do something on native law ... [T] his chap actually knew of me because he'd used some of my work in his own MA thesis, and he said, 'Yah, yah. Oh, I will get a grant and get Barry Hooker to come here.' So they put me in a guesthouse, nothing was too much trouble with a car, a driver, anything ... [And] when Sarawak did this, Sabah had to do it too. So I don't know, got some telephone calls, 'When you finish in Sarawak, you come to Sabah?' 'Okay, I'll come to Sabah.'

\section{KENT}

KT: Then you left? The reason for leaving?

BH: They said to me, 'Look, you are not a Singaporean, you are not a Permanent Resident, you are not a Chinese. You can stay for three years, another three years if you like but you are not going to get promoted.' That was it. That was it... I was lucky, it was made clear to me, so they gave me a three-year contract, I was a very lucky boy to get one... I just received two job offers, so I said, 'Well, no thanks I am leaving.' And they said, 'Well, that's fine. Sign here.'

[The job offers were from] Kent [and] I think it was the ANU (Australian National University) - and I think SOAS (The School of Oriental and African Studies, University of London) was also interested but had not made a firm offer; so, any one of those three. So I thought, 'Well, I have been to Australia, I would go to England.' So, I went to England.

[Kent] had a Law Department but it was a half-time post, and the other half was Southeast Asian Studies as they had started a special centre ... because it was a new university at that time. I started with Southeast Asian Studies; there was a very special department there. There was a big inquiry into universities back then and they decided to expand universities teaching oriental and Asian subjects outside of London. ${ }^{47}$ So they chose Canterbury and Hull ... Durham had always had Arabic and Middle Eastern, so Canterbury got Southeast Asia. So, I went there to do half Southeast Asia, half Law. That was a very strong Southeast Asian Centre and it was actually very good.

[T] here were some good people. Tony Milner was there, Roy Ellen, he's still there. He's an anthropologist; world authority on Eastern Indonesia. Bill Watson Indonesian literature, Rick Vokes economics - Southeast Asian economics; Peter Fitzpatrick for Law - John Basky Philosophy...

$$
* * *
$$

BH: There was no Law School as such but it was a Social Science Faculty and Law was part of the Social Science Faculty ... They didn't have departments, it was very

47. Committee on Higher Education, Higher Education Report of the Committee appointed by the Prime Minister under the Chairmanship of Lord Robbins 196I-I963 (Cmnd 2154, London: Her Majesty's Stationery Office I963). 
democratic. This was the height of democracy in England. It was called a board - Law Board ... there was Board of Anthropology, Law Board.

KT: But would you churn out LLB students or not?

BH: BA; it was either BA or LLB, I forget which now... Yeah, they would do the exemption subjects; the subjects you had to have to pass the bar examination. So instead of sitting the bar exam, the bar would take the university degree as the exempted subjects being passed. Then they would have to go to the bar and do this, that and the other; little bits and pieces.

[It] was very weird because of the university. This was the wave of the revolutionary times; I968 in Paris, then there were the protests in the US in 1970 - burn and throwing down of the gates. And the new universities which were Kent, Sussex, Surrey and East Anglia and especially Kent were Marxists universities. They are full of Marxists, everything was Marx - very left-wing ... The trouble was that the foundation professors had all come from Oxbridge and they were old-fashioned Oxbridge conservatives. The younger members of staff were Marxists and the students were Marxists ... I thought the whole lot of them were a joke and I made it quite clear that you are just a bloody idiot joke; politics is rubbish; Marxist a clown; it doesn't work. That finished me - there was nothing they could do to me.

KT: So you were there to teach Southeast Asian law?

BH: Southeast Asian subjects; I taught everything that was going. History and whatever. History of Islam, a bit of Islam. Then in law, I taught Trusts, Equity all the years - the whole lot.

$$
* * *
$$

KT: You took the [Kent] offer mainly because of this possibility of doing something wider than just law?

BH: No, I just wanted to go and live in England for a while, that's all.... See, I could go back to Australia or New Zealand anytime. I could go back to a university job if I wanted it or I could go back to the farms. If I wanted to go farming, I can do that. So it didn't really matter for me where I went. For money or career, it didn't matter. I was very lucky, again very lucky.

KT: So you wanted to go to live in England?

BH: Mistake, I hated it. Well, I didn't like it much. The longer I was there, the less I liked it.

KT: But you stayed there for twenty years.

BH: Well, my wife wanted [to be] there. 
KT: Would you say those were sort of your golden years in the sense of productivity and materials?

BH: Yeah, because the teaching duties were actually quite light and Southeast Asian studies, I would only teach one or two hours a week. For law, it was more but after we had the old term system - three terms, the third term was essentially just the examination term. So, I only taught two terms in a year and the terms were quite short in Kent. We had the Oxbridge terms - Lent Trinity and Michaelmas. So eight weeks each, so I taught only sixteen weeks a year, that was it ... [T]hen marked the papers and that was it. So the rest of the time was entirely up to me.

So it was very good on that sort of way, plenty of time to write ... I had the time and I had access to the World Asiatic Society Library, British Museum, [and the] SOAS Library. So those three, and the University of London General Library and the London Library. So I had all of these collections... Then across the Channel, I had Leiden - Leiden University Library and then in Paris, I had Bibliothèque Nationale de France - the French library. And then in South of France, if you spend some money and go for holiday there was the Indochinese Colonial Library in Aix-en-Provence.

KT: What about the people; the crowd? Were the people there also rather more interested in Southeast Asian studies in the UK?

$\mathrm{BH}$ : This was the beginning of the big drive by British universities to get foreign students because we charged them higher fees. And so the universities made a profit. Because I was starting to get something of a reputation and Roy Ellen was getting a reputation and so was Rick Vokes. We were getting a lot of students from Malaysia. I was getting the people who had been to Al-Azhar [in Egypt] and they would go to Mecca or Al-Azhar and then come to Canterbury. So I had a constant stream coming through doing Islam, Islamic Studies. And Roy had anthropology students and I think Rick had some economics students because the Economics Board in Canterbury had close links with the Department of Economics at UKM. So, a lot of UKM students came. So we had a huge number of students from Malaysia, that was our mainstream. A few from Singapore, not many.

KT: Would you have been able to stay at Kent had you wanted to?

BH: Yeah, sure, sure. They were terribly upset that I was leaving because I used to bring money. I brought a lot of $\mathrm{PhD}$ and MPhil students ... I was the one who brought the money in. [After] I was gone there was no money coming, they dispersed the rest of them and saved on the administration and so on, so that was it. Yeah, yeah. It was okay as long as I was there but when my money ran out, then that was it ... [W] hen I left, I was the excuse for them to redistribute the rest of them, replace them down, so ... Vokes went to Economics, Ellen went to Anthropology. 
KT: So they just basically dissipated the whole lot of you?

BH: Yeah, that's right and closed the Centre... Which was a big mistake because we used to bring a lot of PhD students; huge. It was actually well known in its day. Quite well known. So I was the excuse for closing it.

\section{$* * *$}

KT: So what happened after twenty years [in Kent]?

BH: Well, my first wife had died, I remarried and Virginia [my present wife] had her job in ANU. I had my job in Canterbury, and I was offered the chair of Oriental Law in London, SOAS, [where] I was external examiner for years ... I was external examiner for Islam, the Arab and non-Arab stream, Southeast Asia, Asia. And then they thought, typical English, well, all Asians are the same, so since you do Asia, you can do China as well. So they roped in China. I said, 'I don't know anything about China.' 'It's alright. Doesn't matter.' ... So I was offered SOAS, I had Canterbury and I was actually fed up of living in England.

\section{AUSTRALIA}

KT: So that's how you ended up in Australia?

BH: Yeah. I had a good time in England, [but] I was getting sick of it, the weather especially. And bored, I get bored very easily. So Virginia had not had her career, so I said, 'Right, I'd give up mine and you have your run.' And we'll buy a farm and I'd go back to farming, which was what we did.

KT: So when you left to go back to Australia, you didn't go back to teaching?

BH: No, no. There were no jobs for me. Virginia asked around and several friends in Monash and so on said, 'You know, here is the world-famous Hooker,' and nobody was interested. The law faculties there are very conservative, you know. The Chinese demand was later.

So I said, 'Well, it doesn't matter. I got that farming.' People don't realize I have this other thing, you know, that I was quite happy to do ... [We] bought a farm and started up again. Yah, I was brought up on a farm ... You can't learn it, you got to be brought up to it.... So I can tell by looking at an animal if I should buy it or not; if it's good or not. And I can breed. I mean stud breeding. It's okay because we did it. I was brought up to start breeders, so I bred stud cattle in Australia. I got a second prize in Sydney. I mean that's competing against Australia's best stud breeders and I came in second. At that level there's no difference between first and second, it's just like that. It's just a point. That showed the local farmers just what I could do, a little bit suspicious you know. Then I got a second in Sydney, they changed, 'Oh, wow, wow!'

There were two [farms] for sale [near Canberra] ... Virginia would have to commute a bit and there were only two possibilities. So, either it's a sheep farm, which I wanted, 
[but] Virginia didn't like the house. So the other one, the cattle farm, which was smaller but the house she liked, so that's where we went ... [we] still live there.

$$
* * *
$$

BH: You have got to be very strong. [The bulls] weigh one ton each you know. Big bulls; I can't do big bulls anymore, cutting their balls off, and then dehorning and so on. I can't do that ... When they are nine months old you choose, so this is your first selection. If they are nine months old, you choose them out, you look at them. Say, that one, that one, that one, the rest no ... they are castrated and fattened up and sold. They sell for meat. The very best ones you keep as stud animals for yourself or for other stud breeders and you sell them ... If you are having a good year, they can fetch $\mathrm{A} \$ 2,000$, maybe $\mathrm{A} \$ 6,000, \mathrm{~A} \$ 8,000, \mathrm{~A} \$ \mathrm{I} 0,000, \mathrm{~A} \$ \mathrm{I}_{2}, 000$, even $\mathrm{A} \$ \mathrm{I}_{5}, 000$ each $\ldots$ in a very good year. But they got to be really top animals.

KT: And only someone who had grown up like this would know what a good animal looks like?

BH: You can't learn it. Yeah, I was lucky. I could remember enough to do it. Even difficult things, I mean if a cow had a calf and the afterbirth hadn't come out, I could take the afterbirth out. I would still remember how to do that ... And shearing, I could still shear. So I used to go on shearing teams as well. The local men, if they were short of a shearer, they would ring me up and say, 'Come and do some work today.' A couple of days' work... I kept the farm going until ... 2004 I think ... so not quite I 5 years, I 4 years. It was very rundown and I had to build it up. Redo the fences, new sheds, plants trees, shelter, lot of garden, organize water and then start breeding, start animals.

KT: And that's when you began to do a little bit more of academic work again?

BH: Yeah, the ANU asked me to go and do some part time lectures in Asian Law... no administration, nothing else. Just teaching and that's it.

\section{REFLECTIONS}

KT: Your body of work, how would you classify them?

BH: Patchy, uneven. Some of it, I should have waited and spent more time on it. Waited for more material, gotten more material, rewritten it - should have been a bit more careful. So some of it is okay, I would pass it now, some of it is... You see, Adat Laws in Modern Indonesia ${ }^{4}$ is a good idea but not done through to what it should have been. Islamic Law in Southeast Asia ${ }^{49}$ is really very good, even looking back. I don't know if it's still used.

48. MB Hooker, Adat Law in Modern Indonesia (OUP I978).

49. MB Hooker, Islamic Law in South-East Asia (OUP I984). 


\section{KT: Legal Pluralism? ${ }^{\circ}$}

BH: Yeah, like you see, I am surprised it's still going. I was lucky because the term 'legal pluralism' was for the first time used in English. It was widely distributed... Yeah, it's a good start-off book for people I think. It's a good late undergraduate or first year postgraduate introduction. So, yeah, I am still actually surprised.

\section{KT: What about Legal History? ${ }^{5 \mathrm{I}}$}

BH: Oh, those big volumes ${ }^{52}$... I would redo that differently. Parts of it are very good actually, really very good. One part is quite weak, I would do it differently now. I mean somebody else can do it. I am not going to do it.

KT: Somebody asked me this question: 'Well, why can't this person do this, this and this?' I said, 'Look, they don't make Barry Hookers and Geoff Bartholomews anymore.' You are a product of a particular time where ...

BH: Yeah, you see, the time was lucky. We were used to working hard and when I came to Singapore, there was a sort of a very uncertain period. Singapore was no longer a colony and it was not part of Malaysia, it was independent. Had not yet got an identity, it was terribly uncertain I am sure. The laws were the old colonial laws continuing, not changing. Already there was impulse to change, to do something different but what to do? It wasn't clear. Same with Malaysia.

It's a very interesting period. The Indonesians had the Dutch war, and then they had Sukarno who wrecked the place, totally wrecked the bloody place ... And the Chinese were still fighting, getting rid of the Americans. So they were still basically straight Marxists, now they are leaving Marxism. The Burmese had been in cold storage since I962.

$$
* * *
$$

BH: [I]f you are looking at Asian Law ... Singapore which is really the only stable and well-educated and prosperous place in the whole region. You got the huge advantage here of stability, infrastructure and money, educated, trained people to do all of this law. Incredible! Could be the leading research university, should be... No reason why not, you know. You've got ... well, even for language, everybody here has got some English plus ... a bit of Chinese, Malay, whatever - and Thai, Khmer; you can learn these languages. Are there language centres here? They teach Thai and Vietnamese?

KT: No, not much.

BH: Oh, for God's sake. There should be a whole bloody Vietnamese, Thai, Laos, Burmese thing here.

50. MB Hooker, Legal Pluralism: An Introduction to Colonial and Neo-colonial Laws (Clarendon Press I975).

5I. MB Hooker, A Concise Legal History of South-East Asia (Clarendon Press I978)

52. MB Hooker, The Laws of South-East Asia: The Pre-Modern Texts, vol I (Butterworths I986); MB Hooker, The Laws of South-East Asia: European Laws, vol 2 (Butterworths I988). 
KT: The trouble with universities like NUS is that they play the rankings game. And as far as they are concerned, they want to play with the big boys and Asian legal studies doesn't attract a lot of attention.

BH: Well, this is the way to do it. The Centre for Asian Languages is in Singapore; the Centre for Asian Legal Studies is in Singapore. I mean why not? I mean Oxford and Cambridge and bloody Yale and Harvard, you are here. You can have the Centre. I mean Cornell's Asian programme has gone to buggery because everybody is dead or retired ... And SOAS has never been much for this area anyway. SOAS has never been much, full stop actually.

KT: Some people say, 'Who wants to know Asian Law?'

BH: Yeah but Asian Law is much more important. African Law is actually basically colonial law, that's all. Asian laws are not colonial laws, they are quite different ... I mean the Chinese in Chinese Academy of Social Sciences Law Institute, for God's sake, incredible. You could do all this here, could be such a fantastic university really.

KT: Alright, last bit. What if anything you would do different or more of if you were say starting out as a young scholar today?

BH: Well, it's difficult for me to say because I am a product of my times and of my particular circumstances. Looking back, I haven't planned anything really very much and I have been incredibly lucky from where I was born and brought up and what I was able to do. Travel and go and so on. Younger people now, in a way it's much easier for them but in another way it's much harder. In my day, there was so much we didn't know, that I could just go out totally untrained and thrash around and do something.

Luckily most of it turned out to be useful; a lot of it would be wasted. Now the material is available for younger people, all they got to do is sit down and learn it, read it. So in that sense easier, in another sense it's harder because the standards are so much higher and they got to know much more and perform much better. So that's really what I am saying. But the chances are more as well and the rewards are greater...

[It's] partly a matter of personality. Some people do big picture thing, I do big picture things.... If you don't want to take risks, that's fine, do something else. Do smaller. But I wouldn't allow students or wouldn't allow younger people to do that initially. I'd say, 'Now, you do your big stuff first, you get the big idea, you would do it big. If you don't like it or you find you can't do it or you fall over or it's no good, okay. Go back, but give it a go first. Don't start off with 'Section $33(\mathrm{c})^{153}$ and stay there for the next 40 years. That's ridiculous. You can't do that; you'll go mad or you will end up in Hotel $8 \mathrm{I}$ in Bencoolen Street.' ${ }^{54}$

53. Hooker was making a generic reference and was not referring to section 33 (c) of any particular statute.

54. 'Hotel $8 \mathrm{I}$ ' is a chain of budget hotels in Singapore and Bencoolen Street - in the middle of town - is known for its many budget hotels and hostels. 